\title{
Improving performance: what pastoral counselors can do?
}

\author{
Yoseph Pedhu ${ }^{1^{*}}$ \\ ${ }^{1}$ Universitas Katolik Indonesia Atma Jaya Jakarta, Indonesia \\ *) Corresponding author, $\equiv \mathrm{e}$-mail: osecp@yahoo.com
}

\begin{abstract}
Pastoral counselor performance is considered to impact on client wellbeing. The performance of pastoral counselors refers to their performance in doing counseling. This article explores performance of pastoral counselors and strategies to improve it. The author examines the concepts and factors that contribute to performance of counselors. Previous research on performance is reviewed. Based on this review, the author elaborates some strategies that can help pastoral counselors improve their performance in carrying out pastoral counseling.
\end{abstract}

Keywords: Strategy, improving, performance, pastoral counselor

How to Cite: Pedhu, Y. (2020). Improving performance: what pastoral counselors can do?. COUNSEDU: The International Journal of Counseling and Education, 5(1), 29-38. DOI: http://doi.org/10.23916/0020200525910

\section{Introduction}

Pastoral counseling plays an essential role in assisting individuals to improve their lives. This special ministry allows pastoral counselors to fully concern with the total wellbeing of clients and encourage them to become a whole person (Lartey, 2002; 2003; Magezi, 2016). Clinebell (2011) expressed that pastoral counseling is a valuable tool that can transform and inspire people to nurture their life journeys. It is a ministry of healing, sustaining, guiding, and reconciling with persons who are distressed whose troubles arise in the context of ultimate meaning and concerns (Clebsch \& Jaekle, 1994; in Woodruff, 2002; in Jacobs, 2004).

Pastoral counseling is a unique form of psychotherapy because it uses both spiritual resources and psychological understanding to facilitate clients in coping constructively with their life problems. American Association of Pastoral Counselors (in Woodruff, 2002) clearly explained the uniqueness of pastoral counseling by stating that "pastoral counseling is a unique form of counseling which uses spiritual resources as well as psychological understanding for healing and growth. It is provided by individuals who are not only mental health professionals but also by persons who have had in-depth religious and/or theological training". Consequently, pastoral counseling as a process to facilitate the growth of clients can only be conducted by person who have had both theological and psychological training.

Cortes (in Sierra, 2014) stated that pastoral counseling is a process in which counselors facilitate clients to manage constructively their conflictual situation. It is a special ministry to help people deal with their experiences of living (Clebsch \& Jaekle, 1994; Gill-Austern, 2003; Woodruff, 2002; Allen, 2014). Pastoral counseling is about giving attention to nurture and empower people to live abundantly (Yeo, 2008; Clinebell \& McKeever, 2011); to help people find possible solutions to acquire the balance of life in relation with God, with others, and with the social environment (Malureanu, 2013; 2014).

Clinebell (2011, in Agilkaya-Sahin, 2016) stated that the task of pastoral counseling is to help people cope with their problems, realize personal possibilities, and remove the obstacles that hinder them from establishing satisfying relations. Pastoral counseling helps people to cope with carrying the burden and 
responsibility of problems, to develop personal possibilities, to establish constructive relations, and to make their relationship with God more meaningful. Pastoral counselors help assess and treat people who prefer psychotherapy that reflects their spiritual beliefs (Sigmund, 2002). In other words, pastoral counseling focuses on the promotion of both psychological and spiritual wellbeing. Pastoral counseling deeply incorporates both psychologicaly and religious rescources so that people who seek counseling have the benefit of spirituality and psychotherapy (Bartoli, 2007; Latini, 2009). Pastoral counseling encompasses theology, faith, and psychotherapy assisting people with addressing a variety of socio-emotional and faithrelated problems (Stansbury, Harley, King, Nelson, \& Speight, 2012).

The integration of theological and psychological discourses forms the uniquness or the identity of pastoral counseling (Foskett \& Lynch, 2001; Woodruff, 2002). Snodgrass (2015) clearly called pastoral counseling as bilingual because pastoral counselors are trained in both theology and psychology. Pastoral counseling is seen as the interdisciplinary use of theology and psychology (Browning, 1985). Pastoral counselors attempt to hold together both scientific and subjective accounts of human existence, which will benefit through a clinical, ethical, and professionaluse of spiritual resources (Richards \& Bergin, 2005).

There are many factors affecting all counselors and other professionals to perform professionally their tasks, one of which is commitment. Commitment is an essential aspect that can affect one's performance in any fields, including in the pastoral counseling profession. It is believed that someone who has high commitment also has high performance (Beer, 2009). In other words, this can be interpreted that an increase in commitment will lead someone to an increase in his/her performance.

The meaning of the term commitment is understood differently by experts. Fink (1992) and Beer (2009), in the context of organization, explains that employee commitment is a key factor that affects performance. Fink (1992) described commitment as an attitude that develops from a process called identification, which occurs when one experiences something, someone, or some idea as an extension of oneself. According to Firestone and Pennell (1993) commitment is a psychological bond or identification of the individual with an object that takes on a special meaning and importance.

The concept of commitment to counseling is important for all counselors, including pastoral counselors as stated by Dollarhide (2003) that counselors must have a strong commitment to carrying out counseling. Commitment to pastoral counseling is a crucial factor that contributes to the performance of pastoral counseling. The higher the commitment of pastoral counselors, the better the performance of pastoral counselors in doing counseling. Commitment to pastoral counseling is referred as the degree to which pastoral counselors want to be engaged in doing counseling. This is reflected through their motivation and involvement to exert their efforts in providing effective counseling. Commitment to counseling gives counselors the responsibility to explore constantly new way of counseling, to work and to improve professional skills, knowledge, and counseling abilities. To be a pastoral counselor means that counselor is required to have strong commitment to organization where he / she works, commitment to pastoral counseling profession, and commitment to the welfare of his / her client.

Counselors need to evaluate periodically their performance. In the school context, Studer and Bundy (2013) stated that counselor evaluation is a critical component to enhance the positive effect that the counselor and the counseling program have on clients (Studer \& Bundy, 2013). Further, Studer and Bundy (2013) explained that the evaluation of counselors' performanceis done based on a job description of their tasks and responsibilities.

The purpose of this article is to explore performance of pastoral counselors and strategies to improve it. This study will hopefully contribute positively both to the development of the science and to the community.

\section{Discussions}

\section{Performance}

Pastoral counselors facilitate counseling services for individuals with the aim of promoting the total wellbeing development. Pastoral counselors provide both individual and group counseling for clients. To professionally implement their task, pastoral counselors are required to possess skills and beliefs and ability to use those skills effectively in which Bandura (1994) reffered as self-efficacy. 
Studies on performance both theoretically and empirically have been carried out, but the understanding of the notion of performance has not yet been agreed upon by experts. This is indicated by the existence of various notions of performance. According to Motowidlo and Van Scotter (in Aboazoum, Nimran, \& Mulsadieq, 2015) performance is the expected organizational value of different behaviors that are shown by employees all the time. Borman and Motowidlo (in Aboazoum, Nimran, \& Mulsadieq, 2015) distinguish two forms of work performance: task performance and contextual performance. Task performance is related to the job description and involves transforming something in goods and services. While contextual performance refers to the behavior of employees who contribute to the effectiveness of the organization through its impact on the work context psychologically, socially, and organizationally.

It is recognized that literature review of pastoral counselor performance in particular is still lacking when compared to other fields, for example in organizational context. Many studies on performance are found in the organizational contexts that conclude performance as the level of success of individuals in completing their work. Mathis and Jakson (2010) stated that performance is essentially related to what employees do or do not do in carrying out their work. Stewart and Brown (2010) described performance as the contribution that individuals contribute to the organizations. They classify three main performance dimensions: task performance, citizenship performance, and counterproductive performance. Task performance is behavior that contributes directly to the production of goods and services. Citizenship performance is behavior that contributes to the positive organizational environment both socially and psychologically, such as helping other employees, giving constructive suggestions on how to improve the organization. Counterproductive performance is behavior that harms the organizationsuch as destroying property, taking unauthorized work breaks, and threatening violence toward coworkers.

Borman and Motowidlo (in Aboazoum, Nimran, \& Mulsadieq, 2015) explained that task performance is related to the description of tasks performed by individuals. In the school setting, the performance of school counselor is evaluated by their performance in managing guidance and counseling program including tasks for planning, designing, implementing, evaluating, and enhancing guidance and counseling (Cobia \& Henderson, 2007; Gysbers \& Henderson, 2012). In the pastoral context, pastoral counselors are evaluated based on their main task in integrating both spiritual and psychological elements in doing counseling as their uniqueness that distinguishes them from other general counseling.

\section{Performance Evaluation}

One of the aspects of developing the dimension of professionalism in the implementation of counseling services is about performance evaluation that needs to be conducted periodically based on a job description that is a result of mutually agreed-upon tasks and goals (Cobia \& Henderson, 2007; Gysbers \& Henderson, 2012; Studer \& Bundy, 2013). In the school counseling context, counselors' performance needs to be evaluated to improve their implementation and the impact of counseling program towards the students and to provide for communication among counselors, guidance program staff leaders, and school administrators (Gysbers \& Henderson, 2012). The evaluation includes counselors' ability to plan, deliver, and evaluate counseling program (Cobia \& Henderson, 2007). While pastoral counselors' performance is evaluated to not only improve their incorporating psychological understanding and spiritual resources but also the impact of counseling towards the welfare of clients.

\section{Factors That Contribute to Performance}

Performance is influenced by many factors. According to Mathis and Jackson (2010), performance is influenced by individual ability, the level of effort spent, and organizational support. Performance is seen as a function of ability, effort, and organizational support. Performance is determined by the individual internal dimensions of ability and effort and external factors. Increasing or decreasing performance is influenced by the interaction of these factors.

Performance is also influenced by satisfaction and dissatisfaction factors at work. Someone who feels happy and satisfied with his or her work is assumed to be able to bring good and optimal work performance. Conversely, someone's displeasure and dissatisfaction with his or her duties and obligations affect the work performance of the individual concerned. Research conducted by Aboazoum, Nimran, and Musadieq (2015) shows that job performance and job satisfaction have a positive and significant relationship. Similar research was also conducted by Almutairi, Moradi, Idrus, Emami, \& Alanazi (2013) showed that there is a positive relationship between job satisfaction and job performance. The results of research on job satisfaction and job performance can be interpreted that an increase in job satisfaction will lead someone to an increase in work performance. 


\section{Studies on performance}

Study on performance has been conducted either in the area of general counseling or in the pastoral context. In the context of general counseling, Little, Packman, Smaby, and Maddux (2005) investigated about the counselor performance and their counseling skills. This study concluded that students who underwent the experimental group Skilled Counselor Training Model (SCTM) had better counseling skills than the control group who did not follow the SCTM. This shows that counselor performance is closely linked with the counseling skills. Similar study was conducted by Schaefle, Smaby, Maddux and Packman (2007) in which they attempted to explore about the performance of counseling skills training based on the theory by looking at the actual counseling sessions. Results showed that there was a positive relationship between a counselor with the counseling skills and counseling performance.

The next study was conducted by Jaafar (2011) to determine the counseling performance among trainee counselor in Malaysia. The study showed majority of respondents have moderate score in their overall counseling performance (86\%), $14 \%$ of them got the high score in their counseling performance, and no respondent got low score in their counseling performance. However, the author recommended that counselor educators still need to give some more effort to ensure that trainee counselor can perform their task in an excellent way.

Lambert (2003; in Leibert, 2011) developed a model of counseling factor that contributes to counseling outcomes. One of the factors is about the use of models or techniques in counseling. The use of appropriate counseling model or technique in accordance with the client's conditions allows for transformation in the counseling process. When orientation and technique are congruent with client worldview, skills and resources, it is more likely that agreement of goals and tasks of treatment are secured (Leibert, 2011).

The study by Schaefle, Smaby, Maddux and Packman (2007) on the performance of counseling skills training based on the specific theory showed that there was a positive relationship between a counselor with the counseling skills and counseling performance. While research conducted by Tsikati (2018) on the factors contributing to effective counselling servicesindicated that counselor training contributes most to effective counselling services. Counselor training is responsible for effective counselling. The author recommends that counselors must receive training in order to provide effective counselling services to their clients.

Study carried out by Madlambayan (2017) aimed to describe students' perceived level of importance and performance of school counselors' roles and functions. Students were asked to rate the importance of school counselor roles and functions and then rate their school counselor's performance based on the same roles and functions. Results of this study revealed that participants perceived all counseling and non counseling functions as very important. Participants also perceived their school counselors demonstrate very good performance on all roles and functions with the exception to the role of school counselor as advocate for their personal/social development. The author recommended that counselors should concentrate on their roles and functions which are very important for students.

Haron, Jaafar, and Baba (2010) studied about the influence of school climate towards counselor's self-efficacy. This study aims to specify whether there is any influence of school climate towards counselor's self-efficacy. The result shows there is a significant relationship between school climate and counselor's self-efficacy. The results of this study can also be used to enhance performance in secondary school counsellor effectiveness through guidance and counselling services provided to students in secondary schools.

In the pastoral counseling context, Young, Griffith, and Williams (2003) investigated about the integral role of pastoral counseling by African-American clergy. The authors investigated about how the clergy understood and carried out any pastoral counseling work. The results showed that many of the respondents reported having and maintaining specialized education for their counseling work, which they described as including both spiritual and psychological dimensions. This study concludes that AfricanAmerican urban ministers functioning as pastoral counselors constitute an engaging and useful group with experiences and skills that can be tapped by interested secular professionals.

Another research wasconducted by Nyandoro (2010) about assessment of counseling skills among the Roman Catholic priests in Masvingo Diocese-Zimbabwe. The result confirmed that there was some 
lack of counseling skills among the clergy. This study indicated that the clergy had pastoral skills but no theoretical base in secular and scientific skills that were needed to blend with pastoral skills. The author recommended that the clergy be well trained in both psychological and pastoral counseling skills.

\section{Strategies to Improve Performance}

On going improvement of counseling performance is a critical component for all counselors. Pastoral counselors are called to address the particular psychological and spiritual needs of client by incorporating those aspects, but this can be harmful to clients if the counselors had no adequate skills. The emerging question for counselors is how to improve their performance. Some strategies that can enable counselors to enhance their performance are discussed.

\section{Professional Development}

Professional development, as viewed as gaining knowledge and skills by keeping up-to-date clinically, managerially, and professionally (Parboosingh, 1998), is the main strategy for counselors to continually strengthen their performance in counseling practice. Ronnestad, Orlinsky, Schroder, Skovholt, and Willutzki (2018) described professional development of counselors as changes in the skillfulness, attitudes, coginitive capacities, emotional and interpersonal functioning and vocational identity of professional counselors. Professional development is considered as an essential tool for enhancing counselors' content knowledge and developing their counseling practice in order to do counseling to a high standard as professionally required by the profession. Continuing professional development aims to increase professional expertise, professional competence and individual wellbeing as well as to increase the competitiveness and effectiveness of organizations and professions (Collin, Van der Heijden, \& Lewis, 2012). Professional development enables counselors to measure not only their current competence to do counseling but also to measure their commitment to expanding their expertise and the boundaries of the body of knowledge, skills and experience of the profession of counseling as a whole (Crockett, 2007, 2010).

Professional development is essential in any profession including in pastoral counseling. Continuing professional development is a core element for all professionals as suggested by Eraut (in Neary, 2016)) that professionals must engage in continual learning to support their professional practice. This supported the idea of considering continuing professional development as a moral duty and part of ethics that frame professional practice. Mulvey (in Neary, 2016) expressed that embracing continuing professional development challenges practitioners to take responsibility for their professional actions.

Pastoral counselors are required specific knowledge, training, and skill in order to perform counseling professionaly. Hence, pastoral counselors need to engage in professional development that enables pastoral counselors to work to a high standard by maintaining and updating their skills and knowledge to ensure they can meet new challenges and improve on existing methods (Crockett, 2007, 2010). It can be done through further education or training, professional work-based activities, self-directed and informal learning, personal activities outside work, courses, seminars and conferences (Crockett, 2007, 2010).

Nyandoro (2010), in his study about assessment of counseling skills among the Roman Catholic priests in Masvingo Diocese-Zimbabwe to examine the competence of the clergy, recommended that the local clergy (pastoral counselor) needs to be well trained in both psychological and pastoral skills in order to increase their performance in doing pastoral counseling. Pastoral counselor needs to be aware of having sufficient knowledge and skills in pastoral counseling. Sufficient knowledge and skills in pastoral counseling requires pastoral counselors to have training not only in theology, biblical studies, ethics, and church history but also in psychological and counseling as well. It is not adequate for counselors to be called as pastoral counselors without understanding and practicing all dimensions into their practice. The practice of pastoral counseling is by its very nature an inter-disiplinary activity which includes theology, biblical studies, psychology, sociology, anthropology, cultural studies and other social sciences (Lynch, 2002). Skilled pastoral counselors should integrate all those aspects in their pastoral counseling practice, because the failure to integrate those dimensions in pastoral counseling indicates that the pastoral counseling has lost its identity and uniqueness (Benner, 2003; in Pedhu, 2019).

Integration of religion/spirituality into the therapeutic practice indicates that pastoral counselors have shown their awareness of client's religious beliefs and background. In pastoral counseling activity, addressing the issue of spiritual is essential. Effective counseling has to address not only the body and the mind, but also the spirit. Counselors can help their clients access spirituality as a strength including spiritual strivings, knowledge, experience, practices, relationships, and coping methods. It is no doubt that Pargament (2007) has already made a very rich contribution to the understanding of how to integrate 
spirituality into psychotherapy. He (2007) argues that sirituality is an extraordinary part of the ordinary lives of people. According to Pargament (2007) spiritual assessment in counseling not only provides useful information for the therapist, but also opens the door to future discussions to openly talk about religious and spiritual life in therapy activity.

The involvement of spiritual elements in counseling requires a firm commitment of counselors to the values of the individual and especially to the values acting for the benefit of the client subjected to a therapeutic approach. At the same time, therapists or counselors are required to have competencies in working with values. West (in Nyandoro, 2010) demonstrated the importance of counseling skill when he wrote that they are like "a laboratory for integrating psychology, theology, and social sciences". Pastoral counselors should have a deep knowledge and skills in integrating theological understanding with psychological insight (Woodruff, 2002).

\section{Developing Counseling Competencies}

Pastoral counseling is significantly different from any other counseling professions. Benner (2003, in Pedhu, 2019) stated that pastoral counselors are the only professionals who have training in systematic theology, biblical studies, ethics, and church history. Pastoral counselors have to integrate both psychological and spiritual rescources in their counseling practice. The failure to integrate those elements indicates that the pastoral counseling has lost its identityand uniqueness (Benner, 2003, in Pedhu, 2019). Pastoral counselors should have counseling skills both in psychology and spiritualitynecessary for making adequate therapeutic progress. In terms of general counseling, Cormier and Hackney (2008) explained counselors should be able to use different counseling skills, ranging from the basic and simple to more advanced and complex levels in the counseling profession. Counselors need to equip themselves with a variety of strategies and interventions to work with clients (Cormier, 2016). Pastoral counselors need the skills to recognize and assist those who come for counseling. Pastoral counselors need to increase their performance by continually developing their counseling competencies both in psychology and spiritual.

American Association of Pastoral Counselors (in Woodruff, 2002) defines pastoral counseling as a unique form of counseling using spiritual resources as well as psychological understanding. It means that pastoral counseling is provided by counselors who have both in mental health and theological/spiritual training (Woodruff, 2002). Therefore, pastoral counselors must learn to be skilled in the methodology of both psychology and theology (Hunsinger in Malureanu, 2014) in order to be effective in doing counseling. Pastoral counselors should have adequate skills and knowledge in carrying out their pastoral tasks. Oates (in Nyandoro, 2010) expressed that pastor as counselors should have adequate counselling skills due to their involvement in counseling people. Pastoral training alone without formal counseling qualification is not adequate to address counseling issues (Kurebwa, Matyatini, \& Wadesango, 2014). To do pastoral counseling professionally is required to have both pastoral training and counseling skills.

The uniqueness of pastoral counseling is about the integration of religion/spirituality in counseling intervention. To provide this unique type of counseling ministry, the integration of pastoral and clinical identities seems to be an essential component in pastoral counselors' professional identity development (Cheney, 2018). Pastoral counselors are demanded to integrate those elements in order to be called as pastoral counseling. Oakes and Raphel (2008, in Walker, Scheidegger, End, \& Amundsen, 2012) stated that in order to integrate religion/spirituality into counseling interventions, pastoral counselors need to develop competency in assessment of clients.

\section{Performance Evaluation}

To better understand the effectiveness of pastoral counseling, it is important for pastoral counselors to evaluate their performance that refers to the effectiveness with which job occupants execute their assigned tasks as defined by Borman and Motowidlo (1997). Therefore, pastoral counselors need to evaluate themselves continuously in performing pastoral counseling to identify their strengths and weakness. The more pastoral counselors evaluate their performance through both self-evaluation and professional evalution by professionals, the higher the chance of their success in helping clients.

Performance evaluation is the process of analyzing on counselors' own skills, personal strengths and limitations. Awarenes in these areas will enable pastoral counselors to get involved in professional development in order to increase their counseling performance. Study conducted by Madlambayan (2017) revealed that counselors should enhance their performance on certain roles and functions based on the evaluation of client. 
The assessment of counseling performance is important for several reasons. Counseling is to help individuals, but sometimes it is harmful to individuals, for example, if the counselor had no skills. Loesch (in Jaafar, 2011)) asserted that the performance of the counselor should be assessed to ensure that the best counselor will be produced from universities so that counseling services provided to clients will benefit them. For assessment purposes, counselors can use reliable and valid assessment tools to evaluate their performance (Tate, Bloom, Tassara, \& Caperton, 2014). This idea also supported by Kerl, Garcia, McCullough and Maxwell (2002), whom insisted that counselor educators have to evaluate trainee counselor to ensure they meet the minimum professionally accepted standards of practice.

\section{Supervision}

Study investigated by Nyandoro (2010) on assessment of counseling skills among the Roman Catholic priest showed that there was some lack of counseling skills among the clergy and he recommended a thorough training and supervision in pastoral counseling. Supervision is an essential and demanding activity to all mental health profession including pastoral counseling (Norcross \& Popple, 2017). Supervision is an integral part of counseling practice and it is central to both counselor education and to the ongoing professional development of all counselors (Ward \& House, 1998). It is an ongoing process of support for counselors to monitor, develop and refine their skills (Bernard \& Goodyear, 2014). Within supervision, pastoral counselors can enhance their skills and knowledge base, ensure responsible and ethical practice and monitor their self-care and professional competence. It is an educational process in which the supervisor and the supervisee can learn from each other about themselves (Hill, 2001).

Pastoral counseling, like any other professions, requires counselors to become more qualified and professional inperforming their jobs. Involvement in supervision service can be an effective way to enhance the performance of counselors (Carroll, 2007). According to Inskipp and Proctor (2001:1) supervision is "a working alliance between the supervisor and counsellor in which the counsellor can offer an account or recording of her work; reflect on it; receive feedback and, where appropriate, guidance. The object of this alliance is to enable the counsellor to gain in ethical competence, confidence, compassion and creativity in order to give her best possible service to the client". Kofler and Cosgrave (1994, in Pedhu, 2019) explained that supervision helps counselors reflect on how they do their work and the issues they are facing in doing counseling. Supervision helps counselors support counselors' professionalism and empower their counseling skills and knowledge (Norcross, 2010; in Pedhu, 2019).

Supervision provides an avenue to encourage counselors focus on better understanding of both the client and themselves (Gabbard \& Wilkinson, 2000, in Pedhu, 2019). Supervision is an educational process in which the supervisor and

the supervisee reciprocally learns about themselves and each other (Hill, 2001). Supervision provides coaching, assists individuals to identify major and minor strengths, keeps counselors refining skills and enlarging the repertoire of clinical responses and intervention, and keeps pastoral counselors focusing on spiritual/theological integration (Woodruff, 2002).

\section{Consultation}

Similar to supervision, pastoral counselors are able to have consultation with a colleague, especially with a senior and experienced counselor. Pastoral counselors can gain new insights related to counseling cases they are facing through consultation. Consultation of a counseling case to a colleague helps counselors get a meaningful feedback which is useful for counseling practice (Pedhu, 2019).

\section{Conclusion}

Pastoral counseling plays an essential role in helping individuals improve their lives comprehensively. Pastoral counselors are concerned with the total wellbeing including mental, physical, emotional, spiritual, and social by incorporating both dimensions of spiritual and psychological.

Pastoral counselors should be aware of how to improve their performance due to its impact to clients. It is generally accepted thatpastoral counselor performance are widely considered to impact positively on client wellbeing as a whole. To maintain the quality of counseling ministry, pastoral counselors need to evaluate periodically their performance. Pastoral counselors are required to continuously seek for the most effective strategies to improve their performance in counseling practice. There are somestrategies that enable pastoral counselors to enhance their performance: professional development, developing counseling competencies, performance evaluation, supervision, and consultation. 


\section{References}

Aboazoum, H. M. E., Nimran, U., \& Mulsadieq, M. A. (2015). Analysis factors affecting employees job performance in Libya. IOSR Journal of Business and Management (IOSR-JBM), 17 (7), 42-49.DOI: $10.9790 / 487 X-17714249$.

Agilkaya-Sahin, Z. (2016). Theoretical foundations of pastoral care in Christian tradition. Spiritual Psychology and Counseling, 1(1), 68-77. DOI: 10.12738/spc.2016.1.0002.

Allen, D. (2014). Pastoral counseling. In David A. Leeming (Ed.), Encyclopedia of psychology and religion. (pp. 1295-1297). New York, NY: Springer Publishing Company.

Almutairi, D. O., Moradi, E., Idrus, D., Emami, R., \& Alanazi, R. (2013). Job satisfaction and job performance: A case study of Five-Star Hotels in Riyadh, Saudi Arabia. World Journal of Social Sciences, 3(1), 27-37.

Bandura, A. (1994). Perceived self-efficacy in cognitive development and functioning. Educational Psychologist, 28, 117-148.

Bartoli, E. (2007). Religious and spiritual issues in psychotherapy practice: Training the trainer. Psychotherapy: Theory, Research, Practice, Training, 44, 54-65.

Benner, D. G. (2003). Strategic pastoral counseling: A short-term structured model. Grand Rapids, MI: Baker Academic.

Bernard, J. M., \& Goodyear, R. K. (2014). Fundamentals of clinical supervision. Boston: Pearson.

Beer, M. (2009). High commitment, high performance: How to build a resilient organization for sustained advantage. San Francisco, CA: Jossey-Bass.

Borman, W. C., \& Motowidlo, S. J. (1997). Task performance and contextual performance: The meaning for personnel selection research. Human Performance, 10(2), 99-109.

Browning, D. S. (1985). Introduction to pastoral counseling. In Robert J. Wicks, Richard D. Parsons, \& Donald E. Capps (Eds.), Clinical handbook of pastoral counseling. (pp.5-13). Mahwah, New Jersey: Paulist Press.

Carroll, M. (2007). One more time: What is supervision? Psychotherapy in Australia, 13(3), 34-40.

Cheney, G. J. (2018). Integrating pastoral and clinical identities: A narrative inquiry of pastoral counselors. Journal of Pastoral Care \& Counseling, 72 (3), 172-179.

Clebsch, W. A. \& Jaekle, C. R. (1994). Pastoral care in historical perspective. New York: Jason Aronson.

Clinebell, H. J. (2011). Basic Types of Pastoral Care and Counseling: Resources for the Ministry of Healing and Growth. Nashville: Abingdon Press.

Clinebell, H. \& McKeever, B. C. (2011). Basic types of pastoral care and counseling: Resources for the ministry of healing \& growth. Nashville: Abingdon Press.

Cobia, D. C., \& Henderson, D. A. (2007). Developing an Effective and Accountability School Counseling Program. Upper Saddle River, New Jersey; Columbus, Ohio: Pearson Education, Inc.

Collin, K., Van der Heijden, B., \& Lewis, P. (2012). Continuing professional development. International Jurnal of Training and Development, 16 (3), 155-163. Doi:10.1111/j.1468-2419.2012.00410.x.

Cormier, S. (2016). Counseling strategies and interventions for professional helpers. Boston, MA: Pearson.

Cormier, S. \& Hackney, H. (2008). Counseling strategies and interventions. Boston, MA: Pearson Education.

Crockett, M. (2007). Continuing professional development and the hallmarks of professionalism: An overview of the current environment for the record-keeping profession. Journal of the Society of Archivists, 28 (1), 77-102.

Crockett, M. (2010). An introduction to continuing professional development. La Gazette des Archives, 218 (2), 21-30. Doi:10.3406/gazar.2010.4662.

Dollarhide, C. T. (2003). School counselors as program leaders: Aplying leadership contexts to school counseling. Professional School Counseling, 6(5), 304-308.

Firestone, W. A., \& Pennell, J. R. (1993). Teacher commitment, working conditions, and differential incentive policies. Review of Educational Research, 63(4), 489-525.

Fink, S. L. 1992. High commitment workplaces. New York: Quorum Books.

Foskett, J., \& Lynch, G. (2001). Pastoral counseling in Britain: An introduction. British Journal of Guidance and Counseling, 29 (4), 373-379.

Gabbard, G. O. \& Wilkinson, S. M. (2000). Management of countertransference with borderline patients. Lanham, MD: Rowman \& Littlefield Publishers, Inc.

Gill-Austern, B. L. (2003). Pastoral counseling: The art of ascetic witnessing. Pastoral Psychology, 52 (1/2), 81-96. 
Gysbers, N. C. \& Henderson, P. (2012). Developing managing your shcool guidence and counseling program. Alexandria, VA: ACA.

Haron, S., Jaafar, W. M. W., \& Baba, M. (2010). The influence of school climate towards counselor's selfefficacy. Procedia Social and Behavioral Sciences, 5, 445-448.

Hill, E. W. (2001). A collaborative pastoral care and counseling supervisory model. The Journal of Pastoral Care. 55 (1), 69-80.

Inskipp, F. \& Proctor, B. (2001). Making the most of supervision. London: Cascade.

Jaafar, W. M. W. (2011). The counseling performance among trainee counselor in Malaysia. Procedia Social and Behavioral Sciences, 30, 512-516.

Jacobs, M. (2004). Pastorl counseling and psychotherapy. In David Willows \& John Swinton (Eds.), Spiritiual dimensions of pastoral care: Practical theology in a multidisiplinary context. (pp.90-94). London \& Philadelphia: Jessica Kingsely Publishers.

Kerl, S. B., Garcia, J. L., McCullough, S., \& Maxwell, M. E. (2002). Systematic evaluation of professional performance: Legally supported procedure and process. Counselor Education and Supervision, 41 (4), 321-334.

Kurebwa, M., Matyatini, J. P., \& Wadesango, N. (2014). An analysis of pastoral counselling practices for married persons among selected Christian Churches in Gweru Urban. Study Tribes Tribals, 12 (1), 43-52.

Lambert, M. J. (2003). Psychotherapy outcome research: Implications for integrative and eclectic therapists. In John C. Norcross \& Marvin R. Goldfried (Eds.), Handbook of Psychotherapy Integration. (pp.94-129). New York: Oxford University Press, Inc. pp. 94-129.

Lartey, E. Y. (2002). Pastoral counseling in multicultural context. American Journal of Pastoral Counseling, 5 (3-4), 317-329.

Lartey, E. Y.. (2003). In Living Color: An Intercultural approach to pastoral care and counseling. London \& New York: Jessica Kingsley Publishers.

Latini, T. F. (2009). Grief-work in light of the cross: illustrating transformational interdisciplinarity. Journal of Psychology and Christianity, 37, 87-95.

Leibert, T. W. (2011). The dimensions of common factors in counseling. International Journal of Advance Counseling, 3, 127-138. DOI 10.1007/s10447-011-9115-7.

Little, C., Packman, J., Smaby, M.H., \& Maddux, C.D. (2005). The skilled counselor training model: Skills acquisition, self-assessment, and cognitive complexity. Counselor Education and Supervision, 44, $189-200$.

Lynch, G. (2002). Pastoral care and counseling. London, Thousand Oaks, New Delhi: Sage Publications.

Madlambayan, J. V. (2017). Students' perceived level of importance and performance of school counselor roles and functions. International Journal of Innovation and Research in Educational Sciences, 4 (4), 456463.

Magezi, V. (2016). Reflection on pastoral care in Africa: Towards discerning emerging pragmatic pastoral ministerial responses. In die Skriflig, 50 (1), 1-7.

Malureanu, A. (2013). Pastoral counseling of the sick. International Journal of Orthodox Theology, 4 (4), 124153.

Malureanu, A. (2014). The meaning, the relevance and the necessity of pastoral counselling in the conceptual perspective. Theologia, 60 (3), 24-33.

Mathis, R. L. \& Jackson. J. H. (2010). Human resource management. Mason, OH: South-Western Cengage Learning.

Milne, D. (2009). Evidence-based clinical supervision: Principles and practices. London, UK: Wiley-Blackwell.

Neary, S. (2016). Only qualifications count: Exploring perceptions of continuing professional development (CPD) within the career guidance sector. British Journal of Guidance \& Counseling, 44 (4), 466-476. Doi: 10.1080/03069885.2016.1180665.

Norcross, A. E. (2010). A case for personal therapy in counselor education. Counseling Today. Retrieved from: https://ct.counseling.org/2010/08/reader-viewpoint/.

Norcross, J. C. \& Popple, L. M. (2017). Supervision essentials for integrative psychotherspy. Washington, DC: American Psychological Association.

Nyandoro, R. (2010). Assessment of counselling skills among the clergy: A case study of The Roman Catholic priests in The Diocese of Masvingo in Zimbabwe. Master Thesis. Pretoria: University of South Africa.

Oakes, K. E. (2008). Spiritual assessment in counseling: methods and practice. Counseling and Values. 52(3), 240-252. 
Pargament, K. I. (2007). Spiritually integrated psychotherapy: Understanding and addressing the sacred. New York, London: The Guilford Press.

Pedhu, Y. (2019). Efforts to overcome countertransference in pastoral counseling relationships. Journal of Pastoral Care \& Counseling, 73(2), 74-81.

Richards, P. S., \& Bergin, A. E. (2005). A spiritual strategy for counseling and psychotherapy. Washington, DC: American Psychological Association.

Ronnestad, M. H., Orlinsky, D. E., Schroder, T. A., Skovholt, T. M., \&Willutzky, U. (2018). The professional development of counselors and psychotherapists: Implication of empirical studies for supervision, training and practice. Counseling and Psychotherapy Research, 19 (3), 214-230.

Schaefle, S., Smaby, M. H., Packman, J., Maddux, C. D. (2007). Performance assessment of counseling skills based on specific theories: Acquisition, retention and transfer to actual counseling sessions. Education, 128 (2), 262-273.

Sierra, J. (2014). Counseling: An expression of the ministry of the Church. The Asbury Journal, 69 (1), 7488.

Sigmund, J. A. (2002). Pastoral counseling: What is it, and when can it help? Current Psychiatry, 1(11), 4957.

Snodgrass, J. L. (2015). Toward holistic care: integrating spirituality and cognitive behavioral therapy for older adults. Journal of Religion, Spirituality \& Aging, 21, 219-236. DOI: 10.1080/15528030902803913.

Stansbury, K. L., Harley, D. A., King, L., Nelson, L., \& Speight, G. (2012). African American Clergy: What are Their Perceptions of Pastoral Care and Pastoral Counseling? Journal Religous Health, 51, 961-969. DOI 10.1007/s10943-010-9413-0.

Stewart, G. L.,\& Brown, K. G. (2010). Human resource management linking strategy to practice. River Street, Hoboken,NJ: John Wiley \& Sons, Inc.

Studer, J. R., \& Bundy, M. L. (2013). A TEAM Approach for Evaluating School Counselors. VISTAS ONLINE, 1-10.

Tate, K. A., Bloom, M. L., Tassara, M. H., \& Caperton, W. (2014). Counselor competence, performance assessment, and program evaluation: Using psychometric instruments. Measurement and Evaluation in Counseling and Development, 47 (4), 291-306. DOI: 10.1177/0748175614538063.

Tsikati. A. F. (2018). Factors contributing to effective guidance and counselling services at University of Eswatini. Global Journal of Guidance and Counselling in Schools: Current Perspectives, 8(3), 139-148.

Walker, K. R., Scheidegger, T. H., End, L., \& Amundsen, M. 2012. The misunderstood pastoral counselor: knowledge and religiosity as factors affecting a client's choice. VISTAS Online. Volume 1, $1-20$.

Ward, C. C., \& House, R. M. (1998). Counseling supervision: A reflective model. Counselor Education and Supervision, 38 (1), 23-33.

Woodruff, C. R. (2002). Pastoral counselling: an American perspective. British Journal of Guidance \& Counselling, 30 (1), 93-101. DOI: 10.1080/030698880220106546.

Yeo, A. (2008). Pastoral care and counseling: An Asian perspective. American Journal of Pastoral Counseling, 5 (3-4), 175-189.

Young, J. L., Griffith, E. E. H., \& Williams, D. R. (2003). The integral role of pastoral counseling by African-American clergy in community mental health. Psychiatric Services, 54 (5), 688-692. 